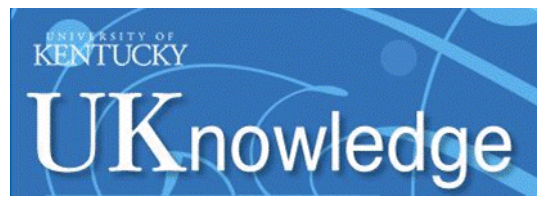

University of Kentucky

UKnowledge

Preventive Medicine and Environmental Health

Faculty Publications

Preventive Medicine and Environmental Health

$10-12-2011$

\title{
Pre- and post-bronchodilator lung function as predictors of mortality in the Lung Health Study
}

\author{
David M. Mannino \\ University of Kentucky, dmannino@uky.edu \\ Enrique Diaz-Guzman \\ University of Kentucky, enriquedgz@uky.edu \\ Sonia Buist \\ Oregon Health Sciences University
}

Follow this and additional works at: https://uknowledge.uky.edu/pmeh_facpub

Part of the Environmental Public Health Commons

Right click to open a feedback form in a new tab to let us know how this document benefits you.

\section{Repository Citation}

Mannino, David M.; Diaz-Guzman, Enrique; and Buist, Sonia, "Pre- and post-bronchodilator lung function as predictors of mortality in the Lung Health Study" (2011). Preventive Medicine and Environmental Health Faculty Publications. 17.

https://uknowledge.uky.edu/pmeh_facpub/17

This Article is brought to you for free and open access by the Preventive Medicine and Environmental Health at UKnowledge. It has been accepted for inclusion in Preventive Medicine and Environmental Health Faculty Publications by an authorized administrator of UKnowledge. For more information, please contact UKnowledge@lsv.uky.edu. 


\section{Pre- and post-bronchodilator lung function as predictors of mortality in the Lung Health Study}

\section{Digital Object Identifier (DOI)}

http://dx.doi.org/10.1186/1465-9921-12-136

\section{Notes/Citation Information}

Published in Respiratory Research, v. 12, 136.

(C) 2011 Mannino et al; licensee BioMed Central Ltd.

This is an Open Access article distributed under the terms of the Creative Commons Attribution License (http://creativecommons.org/licenses/by/2.0), which permits unrestricted use, distribution, and reproduction in any medium, provided the original work is properly cited. 


\title{
Pre- and post-bronchodilator lung function as predictors of mortality in the Lung Health Study
}

David M Mannino ${ }^{1,2^{*}}$, Enrique Diaz-Guzman ${ }^{2}$ and Sonia Buist ${ }^{3}$

\begin{abstract}
Background: Chronic obstructive pulmonary disease (COPD) is supposed to be classified on the basis of postbronchodilator lung function. Most longitudinal studies of COPD, though, do not have post-bronchodilator lung function available. We used pre-and post bronchodilator lung function data from the Lung Health Study to determine whether these measures differ in their ability to predict mortality.

Methods: We limited our analysis to subjects who were of black or white race, on whom we had complete data, and who participated at either the 1 year or the 5 year follow-up visit. We classified subjects based on their baseline lung function, according to COPD Classification criteria using both pre- and post-bronchodilator lung function. We conducted a survival analysis and logistic regression predicting death and controlling for age, sex, race, treatment group, smoking status, and measures of lung function (either pre- or post-bronchodilator. We calculated hazard ratios (HR) with 95\% confidence intervals (Cl) and also calculated area under the curve for the logistic regression models.

Results: By year 15 of the study, 721 of the original 5,887 study subjects had died. In the year 1 sample survival models, a higher $\mathrm{FEV}_{1} \%$ predicted lower mortality in both the pre-bronchodilator ( $\mathrm{HR} 0.87,95 \% \mathrm{Cl} 0.81,0.94$ per $10 \%$ increase) and post-bronchodilator (HR 0.84, 95\% Cl 0.77, 0.90) models. The area under the curve for the respective models was $69.2 \%$ and $69.4 \%$. Similarly, using categories, when compared to people with "normal" lung function, subjects with Stage 3 or 4 disease had similar mortality in both the pre- (HR 1.51,95\% Cl 0.75, 3.03) and post-bronchodilator (HR 1.45, 95\% Cl 0.41, 5.15) models. In the year 5 sample, when a larger proportion of subjects had Stage 3 or 4 disease (6.4\% in the pre-bronchodilator group), mortality was significantly increased in both the pre- (HR 2.68, 95\% Cl 1.51, 4.75) and post-bronchodilator ( $\mathrm{HR} 2.46,95 \% \mathrm{Cl} 1.63,3.73$ ) models.
\end{abstract}

Conclusions: Both pre- and post-bronchodilator lung function predicted mortality in this analysis with a similar degree of accuracy. Post-bronchodilator lung function may not be needed in population studies that predict longterm outcomes.

Keywords: COPD, mortality, epidemiology, bronchodilator responsiveness

\section{Background}

COPD is a chronic disease of the lungs and is characterized by irreversible airflow limitation, and is currently the third leading cause of death in the United States [1-3]. GOLD defines COPD as a preventable and treatable disease with airflow limitation that is usually progressive and associated with an abnormal inflammatory response of the lung to noxious particles or gases [4]. Both the American Thoracic Society (ATS) and the

\footnotetext{
* Correspondence: dmannino@uky.edu

'University of Kentucky, College of Public Health, Lexington, KY, USA Full list of author information is available at the end of the article
}

European Respiratory Society (ERS) have, in large part, adopted this definition [5].

Response to a bronchodilator is thought to be important in COPD diagnosis and guidelines suggest that classification of COPD be made using spirometry performed after bronchodilator administration [4]. While asthma generally has more reversibility to a bronchodilator than COPD, the presence of reversibility does not distinguish asthma from COPD [6].

According to the 2008 GOLD guidelines "Spirometry should be performed after the administration of an adequate dose of an inhaled bronchodilator (e.g., $400 \mu \mathrm{g}$

\section{() Biomed Central}

() 2011 Mannino et al; licensee BioMed Central Ltd. This is an Open Access article distributed under the terms of the Creative Commons Attribution License (http://creativecommons.org/licenses/by/2.0), which permits unrestricted use, distribution, and reproduction in any medium, provided the original work is properly cited. 
salbutamol) [7] in order to minimize variability. In a random population study to determine spirometry reference values, post-bronchodilator values differed from pre-bronchodilator values [8]. Furthermore, postbronchodilator lung function testing in a community setting has been demonstrated to be an effective method to identify individuals with COPD $[9,10]$. However, most longitudinal studies looking at the effect of impaired lung function on outcomes such as mortality and hospitalizations have used pre-bronchodilator lung function [11-14].

The purpose of this study is to determine whether pre- or post-bronchodilator lung function differentially predict mortality in cohorts over time. Data from the Lung Health Study [15] was used in this analysis.

\section{Methods}

The Lung Health Study (LHS) was a randomized multicenter clinical trial that was carried out from October 1986 through April 1994 [15,16]. A detailed description of the LHS design has been previously published [16]. Briefly, "healthy" current smokers between the ages of 35 and 60 were enrolled if their forced expiratory volume in one second $\left(\mathrm{FEV}_{1}\right)$ to forced vital capacity (FVC) was less than $70 \%$ and their $\mathrm{FEV}_{1}$ was between $55 \%$ and $90 \%$ of the predicted normal value. Subjects were randomized into three groups: a control group receiving "usual care", a smoking intervention group receiving placebo, and a smoking intervention group receiving the bronchodilator ipratroprium. Lung function was measured before and after two inhalations (200- $\mu$ g total dose) of isoproteronol from a metered-dose inhaler.

We used data from the year 1 (one year following baseline) and year 5 (5 years following baseline) visits and included subjects who had complete data and both pre- and post-bronchodilator lung function measurements at these visits. The rationale for using these visits was that the inclusion criteria limited the range of lung disease severity at baseline to mild and moderate COPD, whereas a broader range could be seen in subsequent visits. In addition, prior work has demonstrated that bronchodilator responsiveness was larger in year 1 and subsequent years than it was at baseline [17].

About $75 \%$ of the original cohort of 5887 participants were followed continuously for 10 years beyond the 5year time frame of Lung Health Study I (these subjects were mostly participants in Lung Health Study III) by biannual phone contacts (to ascertain vital status, smoking status, morbidity and mortality). Our primary endpoint was all-cause mortality at up to 14.5 years of follow-up from baseline [18]. The time metric used was time from the year 1 examination to the time of death or the end of the study or from the year 5 examination to the end of the study.

\section{Study Measures}

Predicted values from the Third National Health and Nutrition Examination Survey (NHANES III) were used in the analysis [19]. We used age, sex, height and race to determine the predicted values. The study participants were classified, using the pre- and post-bronchodilator lung function, into five lung function categories based on a modification of COPD classification criteria: Normal (no airflow obstruction or restriction), restricted $\left(\mathrm{FEV}_{1} / \mathrm{FVC} \geq 70 \%\right.$ and $\mathrm{FVC}<80 \%$ of predicted), Stage 1 $\left(\mathrm{FEV}_{1} / \mathrm{FVC}<70 \%\right.$ and $\mathrm{FEV}_{1} \geq 80 \%$ predicted), Stage 2 $\left(\mathrm{FEV}_{1} / \mathrm{FVC}<70 \%\right.$ and $50 \% \leq \mathrm{FEV}_{1}<80 \%$ predicted $)$, and Stage 3 or $4\left(\mathrm{FEV}_{1} / \mathrm{FVC}<70 \%\right.$ and $\mathrm{FEV}_{1}<50 \%$ predicted) [4].

\section{Definitions}

Demographic data included in this analysis were sex, age, body mass index (BMI), smoking status, race, and educational status. Age was classified at baseline, the year 1, and year 5 examinations and was categorized for use in tables (35-39, 40-49, 50-50, and 60 and older), and was used as a continuous variable in the survival analyses. BMI was categorized at baseline and was categorized into 3 categories $(<25,25-29$, and $>=30 \mathrm{~kg} /$ $\mathrm{m}^{2}$ ), and was used as a continuous variable in the survival analyses. All subjects were smokers at baseline, so smoking status was classified based on their second through fifth follow-up visits as current smokers for those who never stopped smoking, former smokers for those who successfully quit, and intermittent smokers for those whose status varied [20]. Education status was stratified into three levels $(<12$ years, 12 years, and $>12$ years). Race was classified as White or Black, with people of other races excluded. The original design of the study was incorporated by stratifying the subjects by randomization group: Intervention with ipratroprium, Intervention with placebo, and Control.

\section{Statistical Analysis}

Data analysis was completed using statistical software (Statistical Analysis Software, version 9.2; SAS Institute; Cary, NC and SUDAAN version 10.1; RTI, Research Triangle Park, NC). Our primary outcome of interest in the survival models was mortality, and the main predictor of interest in our analysis was COPD severity defined by stage of lung function, both pre- and postbronchodilator, and a separate analysis using $\mathrm{FEV}_{1}$ as a percent of predicted, both pre- and post-bronchodilator. We calculated the deaths per 1,000 person years of follow-up for our key covariates. Cox proportional hazard regression models were developed using the SUDAAN procedure SURVIVAL to account for differential follow up in cohort participants. Time of follow up was used as the underlying time metric. Censoring occurred at 
the date of death certificate or date the participant was last known to be alive. Plots of the log-log survival curves for each covariate were produced to evaluate the proportional hazards assumptions. Age, sex, race, smoking status, education level, body mass index and randomization cohort were included in the adjusted models.

\section{Results}

There were a total of 5,887 participants in the Lung Health Study, of whom 721 died by the end of the follow-up period of up to 15 years. The major causes of death at follow-up were lung cancer and cardiovascular disease with comparatively fewer deaths due to nonmalignant respiratory disease. At baseline, the mean age of the cohort was 48.5 years and the mean $\mathrm{FEV}_{1}$ was $74.7 \%$. Of these, we had complete data on 5,307 who participated in the examination at year 1 (there were 13 deaths before the year 1 visit). Among the 5,307 on whom we had complete data at year 1, we had 65,472 person years of follow-up, with a median and maximum follow-up time of 12.8 and 14.0 years, and 628 deaths (Table 1). Among the 5,320 on whom we had complete data at year 5 (there were 149 deaths prior to the year 5 visit), we had 45,808 person years of follow-up, with a median and maximum follow-up time of 8.8 and 10.0 years, and 500 deaths (Table 2).

Table 1 provides additional detail on the covariates of the cohort at year 1 , including the total follow-up time and the mortality rate per 1,000 person-years of followup. As would be expected, age was the strongest predictor of mortality. Similar data for the Year 5 cohort is displayed in Table 2.

Changes in the COPD classification stages between pre- and post-bronchodilator lung function measurements for the year 1 and the year cohort is shown in Table 3. At year 1, 3,804 of 5,307 (71.7\%) remained in the same category for both pre- and post-bronchodilator $\mathrm{FEV}_{1}$ and at year 5, 4,079 of 5,320 (76.7\%) remained in the same category for both pre- and post-bronchodilator $\mathrm{FEV}_{1}$. The mean $\mathrm{FEV}_{1}$, as a percentage of predicted, increased from 74.1\% (Standard deviation [SD] 10.3\%) to $78.1 \%$ (SD 10.0\%) at year 1 and from 70.3\% (SD $12.5 \%)$ to $74.3 \%$ (SD $12.1 \%$ ) at year 5 .

The Cox proportional hazards models for the year 1 cohort are shown in Table 4. Age, sex, education level, race, and smoking status were significant predictors of mortality, but in these models COPD classification stage reached statistical significance in only stage 2 of the post-bronchodilator model. The area under the curve, from the PROC logistic model, was $69.2 \%$ for the preand $69.6 \%$ for the post- bronchodilator model. In parallel models that used pre- and post-bronchodilator $\mathrm{FEV}_{1}$, as a percentage of predicted, a higher $\mathrm{FEV}_{1} \%$ predicted lower mortality in both the pre- (HR 0.87, 95\% CI 0.81,
0.94 per $10 \%$ increase) and post-bronchodilator (HR $0.84,95 \%$ CI $0.77,0.90)$ models. The area under the curve for the respective models was $69.2 \%$ and $69.4 \%$.

Similar models for the year 5 follow-up data are shown in Table 5 . The main difference seen between the year 1 and year 5 models is that the latter now show an increased risk of Stage 3 or 4 COPD on mortality in both the pre- (HR 2.68, 95\% CI 1.51, 4.75) and postbronchodilator (HR 2.46, 95\% CI 1.63, 3.73) models. The area under the curve was $69.0 \%$ for the pre- and $69.5 \%$ for the post-bronchodilator models. Similar models using $\mathrm{FEV}_{1}$ showed that a higher $\mathrm{FEV}_{1} \%$ predicted lower mortality in both the pre-bronchodilator (HR $0.84,95 \%$ CI $0.75,0.87$ per $10 \%$ increase) and postbronchodilator (HR 0.78, 95\% CI 0.73, 0.90) models. The area under the curve for the respective models was $69.4 \%$ and $69.8 \%$.

\section{Discussion}

This analysis examined data from the Lung Health Study to determine whether post-bronchodilator lung function predicts mortality. Overall, we found that the pre- and post-bronchodilator measures of lung function, whether used categorically (as stages of COPD) or continuously (as $\mathrm{FEV}_{1} \%$ predicted) predicted mortality similarly. This finding suggests that post-bronchodilator lung function data may not be needed for studies that look at long term outcomes in COPD.

Most guidelines defining COPD say that spirometry should be performed after the administration of an adequate dose of an inhaled bronchodilator in order to minimize variability $[4,21]$. These same guidelines, however, state that "neither bronchodilator nor oral glucocorticosteroid reversibility testing predicts disease progression, whether judged by decline in $\mathrm{FEV}_{1}$, deterioration of health status, or frequency of exacerbations in patients with a clinical diagnosis of COPD and abnormal spirometry. Small changes in $\mathrm{FEV}_{1}$ (e.g., < $400 \mathrm{ml}$ ) after administration of a bronchodilator do not reliably predict the patient's response to treatment" [4]. Others have suggested that one cannot use prebronchodilator lung function to define COPD, the reason being that airflow limitation can be variable and that this component can be easily reverse with a bronchodilator [22]. Other research, though, has suggested that bronchodilator responsiveness is highly variable and that "over half the patients initially classified as reversible by the ATS/ GOLD definition would be reclassified had they attended on another occasion" [23].

In population-based studies, one would expect that post-bronchodilator lung function measurement would reduce the prevalence of COPD. For example, in the PLATINO study, bronchodilator testing reduced the overall prevalence of $\mathrm{FEV}_{1} / \mathrm{FVC} \%<0.70$ from $21.7 \%$ to 
Table 1 Characteristics of Analyzed Population at Year 1 $(n=5,307)$ with 628 deaths at up to 15 years of followup

\begin{tabular}{lrrcl}
\hline & N & \% & $\begin{array}{c}\text { Person-Years of } \\
\text { Follow-up }\end{array}$ & $\begin{array}{l}\text { Deaths per 1,000 } \\
\text { Person Years }\end{array}$ \\
\hline Sex & & & & \\
$\quad$ Female & 1993 & 37.6 & 24,764 & 8.3 \\
$\quad \begin{array}{l}\text { Male } \\
\text { Age Group, Years }\end{array}$ & 3314 & 62.4 & 40,708 & 10.4 \\
35-39 & 522 & 9.8 & 6,610 & 3.8 \\
$40-49$ & 2099 & 39.6 & 26,350 & 5.5 \\
$50-59$ & 2494 & 47.0 & 30,267 & 13.7 \\
$60+$ & 192 & 3.6 & 2,245 & 18.7
\end{tabular}

Body Mass Index $\mathrm{kg} / \mathrm{m}^{2}$

$$
\begin{aligned}
& <25 \\
& 25-30 \\
& >=30
\end{aligned}
$$

8,513

11.5

Education, Years

$<12$
12

\section{$632 \quad 11.9$
-1}

7,720

$>12$

$1592 \quad 30.0$

308358.1

19,629

38,123

13.0

Race

White

$$
\begin{array}{ll}
5108 \quad 96.3 \\
199 & 3.7
\end{array}
$$

63,117

$199 \quad 3.7$

$$
\text { 2,355 }
$$

Smoking Status

Former
Intermittent
Current

$$
\begin{array}{ll}
1439 & 27.1
\end{array}
$$

\section{7,966}

7,752

39,754

$3240 \quad 61.1$

Randomization

Group

$\begin{array}{lrrrr}\begin{array}{l}\text { Intervention, } \\ \text { Ipratroprium }\end{array} & 1793 & 33.8 & 22,141 & 8.9 \\ \begin{array}{l}\text { Intervention, } \\ \text { Placebo }\end{array} & 1785 & 33.6 & 22,108 & 9.0 \\ \text { Control } & 1729 & 32.6 & 21,223 & 11.0\end{array}$

Stage (pre-

bronchodilator)*

$\begin{array}{lrrcl}\text { Stage } 3 \text { or } 4 & 67 & 1.3 & 799 & 15.0 \\ \text { Stage } 2 & 3432 & 64.7 & 42,208 & 10.7 \\ \text { Stage } 1 & 1354 & 25.5 & 16,852 & 7.3 \\ \text { Restricted } & 69 & 1.3 & 840 & 9.5 \\ \text { Normal } & 385 & 7.3 & 4,773 & 6.7\end{array}$

Stage (post-

bronchodilator)*

\begin{tabular}{lrrcl} 
Stage 3 or 4 & 19 & 0.4 & 224 & 13.4 \\
Stage 2 & 2540 & 47.9 & 31,126 & 12.1 \\
Stage 1 & 1565 & 29.5 & 19,386 & 7.8 \\
Restricted & 125 & 2.4 & 1,487 & 12.1 \\
Normal & 1058 & 19.9 & 13,249 & 5.8 \\
\hline
\end{tabular}

*Modified chronic obstructive pulmonary disease stage, as defined in methods

$14 \%$ [24]. In our analysis the prevalence of severe COPD was lower in the post- compared to the pre-bronchodilator lung function in both the year $1(0.4 \%$ vs. $1.3 \%)$
Table 2 Characteristics of Analyzed Population at Year 5 $(n=5,320)$ with 500 deaths at up to 10 years of followup

\begin{tabular}{lrrcl}
\hline & N & $\%$ & $\begin{array}{c}\text { Person-Years } \\
\text { of Follow-up }\end{array}$ & $\begin{array}{l}\text { Deaths per 1,000 } \\
\text { Person Years }\end{array}$ \\
\hline Sex & & & & \\
$\quad$ Female & 1,992 & 37.4 & 17,221 & 9.4 \\
$\quad \begin{array}{l}\text { Male } \\
\text { Age Group, years }\end{array}$ & 3,328 & 62.6 & 28,587 & 11.8 \\
$35-39$ & & & & \\
$40-49$ & 25 & 0.5 & 214 & 9.3 \\
$50-59$ & 1,708 & 32.1 & 14,995 & 4.7 \\
$60+$ & 2,436 & 45.8 & 20,954 & 11.4 \\
& 1,151 & 21.6 & 9,644 & 19.7
\end{tabular}

Body Mass Index, kg/ m2

$\begin{array}{lrrrr}<25 & 2,536 & 47.7 & 21,849 & 10.7 \\ 25-30 & 2,098 & 39.4 & 18,075 & 10.6 \\ >=30 & 686 & 12.9 & 5,884 & 12.7\end{array}$

Education (years)

$\begin{array}{lrrrr}<12 & 639 & 12.0 & 5,496 & 14.0 \\ 12 & 1,595 & 30.0 & 13,735 & 11.5 \\ >12 & 3,086 & 58.0 & 26,577 & 10.0\end{array}$

Race

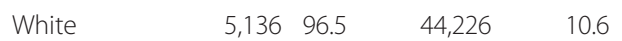

$\begin{array}{lllll}\text { Non-White } & 184 & 3.5 & 1,582 & 19.6\end{array}$

Smoking Status

$\begin{array}{lrlcl}\text { Former } & 1,386 & 26.1 & 12,063 & 7.5 \\ \text { Intermittent } & 627 & 11.8 & 5,403 & 10.2 \\ \text { Current } & 3,307 & 62.2 & 28,342 & 12.5\end{array}$

Randomization Group

$\begin{array}{lrrrr}\begin{array}{l}\text { Intervention, } \\ \text { Ipratroprium }\end{array} & 1,791 & 33.7 & 15,470 & 9.6 \\ \begin{array}{l}\text { Intervention, } \\ \text { Placebo }\end{array} & 1,770 & 33.3 & 15,271 & 10.5 \\ \text { Control } & 1,759 & 33.1 & 15,067 & 12.7\end{array}$

Stage (prebronchodilator)*

$\begin{array}{lrrcl}\text { Stage } 3 \text { or } 4 & 341 & 6.4 & 2,831 & 21.5 \\ \text { Stage } 2 & 3,587 & 67.4 & 30,875 & 11.3 \\ \text { Stage } 1 & 995 & 18.7 & 8,674 & 7.3 \\ \text { Restricted } & 92 & 1.7 & 768 & 15.6 \\ \text { Normal } & 305 & 5.7 & 2,659 & 5.6\end{array}$

Stage (postbronchodilator)*

$\begin{array}{lrrrl}\text { Stage } 3 \text { or } 4 & 183 & 3.4 & 1,475 & 29.8 \\ \text { Stage } 2 & 3,048 & 57.3 & 26,237 & 12.0 \\ \text { Stage } 1 & 1,242 & 23.3 & 10,775 & 7.2 \\ \text { Restricted } & 126 & 2.4 & 1,059 & 13.2 \\ \text { Normal } & 721 & 13.6 & 6,262 & 7.8\end{array}$

*Modified chronic obstructive pulmonary disease stage, as defined in methods

and the year 5 (3.4\% vs. $6.4 \%)$ cohorts. The finding of a lower prevalence, however, does not necessarily mean that this is the correct prevalence. 
Table 3 Comparison of pre- and post-bronchodilator classifications from Year 1 and Year 5 visits

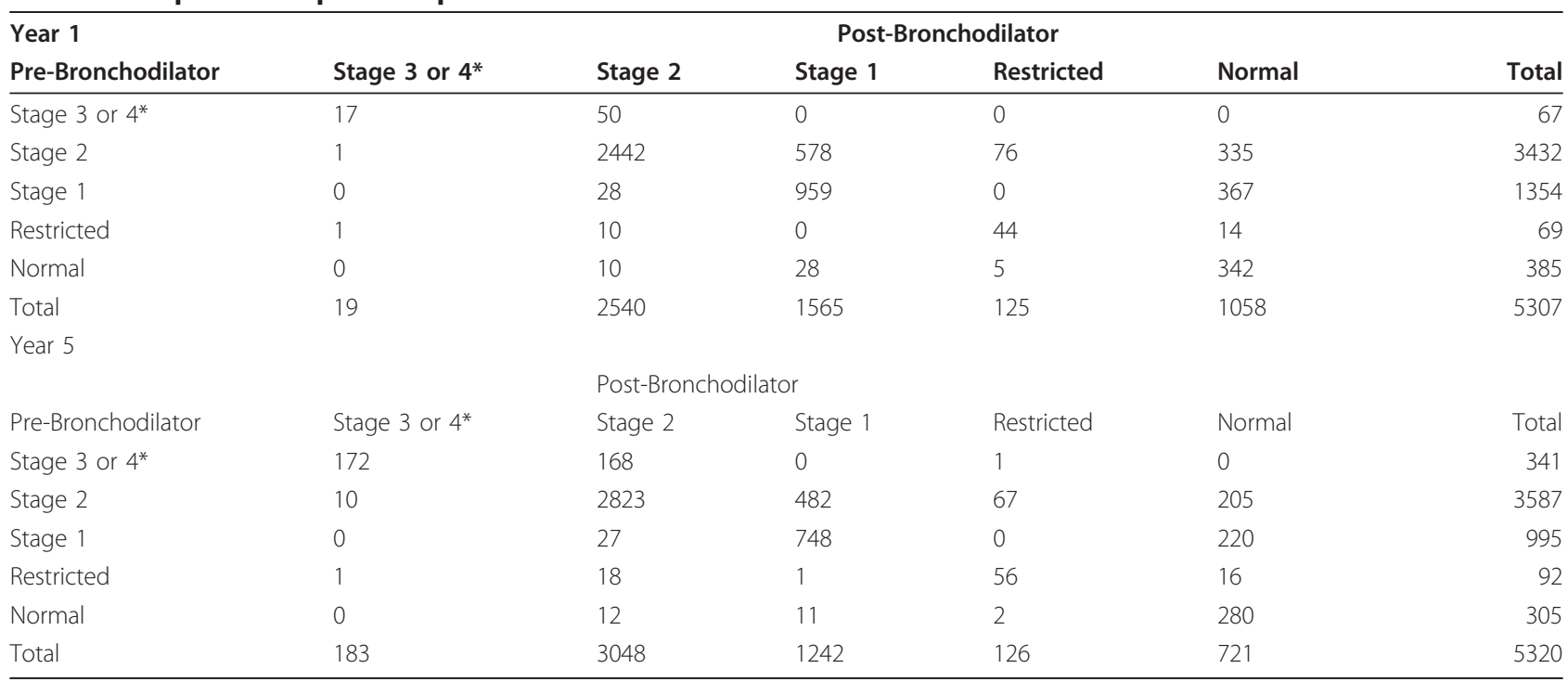

The rows represent the pre-bronchodilator values and the columns represent the post-bronchodilator values (i.e. at year one $67 / 5307$ were stage 3 or 4 pre- and 19/5307 were stage 3 or 4 post-bronchodilator). Year 1 Post-Bronchodilator

*Modified chronic obstructive pulmonary disease stage, as defined in methods

Others have looked at this problem in different ways. For example, Hansen et al studied 985 patients with COPD and found that the response to a bronchodilator was a positive prognostic factor along with $\mathrm{FEV}_{1}$ at baseline. However, if baseline $\mathrm{FEV}_{1}$ was substituted with postbronchodilator $\mathrm{FEV}_{1}$, the bronchodilator reversibility became nonsignificant [25]. Compared to our population, that population had much lower lung function (mean $\mathrm{FEV}_{1} 38.5 \%$ of predicted compared to our mean $\mathrm{FEV}_{1}$ of $74.7 \%$ ) and was much older (mean age 61.8 years at baseline compared to our mean age of 48.5 years). Still, the predictive value for $\mathrm{FEV}_{1}$ in their study was similar in the pre- (relative risk [RR] 0.60, 95\% CI $0.54,0.81$ ) and postbronchodilator (RR $0.62,95 \%$ CI 0.56, 0.69) models.

Burrows acknowledged the complexity of the relation between bronchodilator responsiveness and outcomes in obstructive lung disease [26]. He noted that different studies had varying results $[27,28]$ and suggested that several factors, such as how baseline lung function is determined, how responsiveness is measured, and the prevalence of "asthma" in the studied population, may be important determinants of outcomes. His conclusion that mortality is "related to age and to a low initial postbronchodilator $\mathrm{FEV}_{1}$ " provides, in part, the historic rationale for using post-bronchodilator lung function to define COPD.

This study has limitations that are important to its interpretation. The most important was that it was not a true "population-based" study but was a clinical intervention trial that targeted early COPD. Study participants had to be current smokers at entry with lung function that was mildly abnormal, and subjects who regularly used bronchodilators were excluded. Although asthma history was not a specific exclusion criterion, excluding people with regular bronchodilator use had the net effect of eliminating subjects with clinically significant asthma from the population. Thus, these findings may not necessarily apply to a population that includes never smokers or where a large proportion of the population has asthma that is symptomatic. Also, a more inclusive population of smokers where reversibility is more common may have yielded different results. This limitation is decreased by our study design that looked at data from the year 1 and year 5 follow-up, at which point some subjects had stopped smoking and many developed symptoms consistent with asthma or COPD. In addition, one would not expect the post-bronchodilator $\mathrm{FEV}_{1}$ of never smokers (in the absence of asthma) to differ significantly from the pre-bronchodilator value. Finally, the dose of bronchodilator used in this study (two inhalations, 200- $\mu$ g total dose, of isoproterenol) is less than what has been used in other clinical trials, some of which have used $400 \mu \mathrm{g}$ of isoproterenol and $400 \mu \mathrm{g}$ of albuterol [29]. Thus, it is unknown whether the findings would be similar if a "maximal bronchodilitation" protocol was used.

Another limitation was the absence of other important measures of COPD, such as an impaired exercise testing, impaired diffusion capacity or abnormal imaging. Recent work [30-32] in COPD has highlighted that measures other than lung function are important predictors of impaired function and poor outcomes. Lung function remains, however, the primary means of diagnosing and 
Table 4 Results from Cox Proportional hazards survival models on year 1 sample- Mortality follow-up of up to 15 years

\begin{tabular}{|c|c|c|}
\hline & $\begin{array}{l}\text { Hazards } \\
\text { Ratio }\end{array}$ & $\begin{array}{r}95 \% \text { Confidence } \\
\text { Interval }\end{array}$ \\
\hline \multicolumn{3}{|l|}{ Sex } \\
\hline Male & 1.34 & $(1.12,1.59)$ \\
\hline Female & 1.00 & \\
\hline Age & 1.09 & $(1.07,1.10)$ \\
\hline Body Mass Index & 1.00 & $(0.98,1.03)$ \\
\hline \multicolumn{3}{|l|}{ Education } \\
\hline$<12$ Years & 1.29 & $(1.03,1.61)$ \\
\hline 12 Years & 1.08 & $(0.90,1.29)$ \\
\hline$>12$ Years & 1.00 & \\
\hline \multicolumn{3}{|l|}{ Race } \\
\hline White & 1.00 & \\
\hline Black & 2.13 & $(1.57,2.88)$ \\
\hline \multicolumn{3}{|l|}{ Smoking Status } \\
\hline Former Smoker & 0.64 & $(0.52,0.79)$ \\
\hline Intermittent Smoker & 0.89 & $(0.69,1.15)$ \\
\hline Current Smoker & 1.00 & \\
\hline \multicolumn{3}{|l|}{ Randomization Group } \\
\hline $\begin{array}{l}\text { Intervention, } \\
\text { Ipratroprium }\end{array}$ & 0.92 & $(0.76,1.12)$ \\
\hline Intervention, Placebo & 0.89 & $(0.74,1.09)$ \\
\hline Control & 1.00 & \\
\hline \multicolumn{3}{|l|}{ Stage (Pre-bronchodilator)* } \\
\hline Stage 3 or 4 & 1.51 & $(0.75,3.03)$ \\
\hline Stage 2 & 1.36 & $(0.95,1.95)$ \\
\hline Stage 1 & 0.97 & $(0.65,1.44)$ \\
\hline Restricted & 1.12 & $(0.51,2.48)$ \\
\hline Normal & 1.00 & \\
\hline \multicolumn{3}{|l|}{ Stage (Post-bronchodilator) } \\
\hline Stage 3 or 4 & 1.45 & $(0.41,5.15)$ \\
\hline Stage 2 & 1.54 & $(1.20,1.98)$ \\
\hline Stage 1 & 1.06 & $(0.80,1.40)$ \\
\hline Restricted & 1.63 & $(0.96,2.75)$ \\
\hline Normal & 1.00 & \\
\hline
\end{tabular}

Results for post-bronchodilator lung function measurement is displayed without showing results for the other covariates.

*Modified chronic obstructive pulmonary disease stage, as defined in methods

classifying COPD at the present time and this is unlikely to change in the foreseeable future.

\section{Conclusion}

We found that is this cohort both pre- and post-bronchodilator lung function predicted mortality with similar accuracy. This validates the approach taken in a number of long-term studies where only prebronchodilator lung function is available, although studies that include similar data in never smokers and subjects with asthma are needed.
Table 5 Results from Year 5 sample, mortality follow-up of up to 10 years

\begin{tabular}{|c|c|c|}
\hline & $\begin{array}{l}\text { Hazards } \\
\text { Ratio }\end{array}$ & $\begin{array}{r}95 \% \text { Confidence } \\
\text { Interval }\end{array}$ \\
\hline \multicolumn{3}{|l|}{ Sex } \\
\hline Male & 1.36 & $(1.12,1.64)$ \\
\hline Female & 1.00 & \\
\hline Age & 1.09 & $(1.07,1.10)$ \\
\hline Body Mass Index & 1.01 & $(0.98,1.03)$ \\
\hline \multicolumn{3}{|l|}{ Education } \\
\hline$<12$ Years & 1.24 & $(0.96,1.59)$ \\
\hline 12 Years & 1.10 & $(0.90,1.34)$ \\
\hline$>12$ Years & 1.00 & \\
\hline \multicolumn{3}{|l|}{ Race } \\
\hline White & 1.00 & \\
\hline Black & 1.77 & $(1.22,2.56)$ \\
\hline \multicolumn{3}{|l|}{ Smoking Status } \\
\hline Former Smoker & 0.63 & $(0.50,0.80)$ \\
\hline Intermittent Smoker & 0.85 & $(0.64,1.13)$ \\
\hline Current Smoker & 1.00 & \\
\hline \multicolumn{3}{|l|}{ Randomization Group } \\
\hline $\begin{array}{l}\text { Intervention, } \\
\text { Ipratroprium }\end{array}$ & 0.86 & $(0.69,1.07)$ \\
\hline Intervention, Placebo & 0.91 & $(0.74,1.13)$ \\
\hline Control & 1.00 & \\
\hline \multicolumn{3}{|l|}{ Stage $\left(\right.$ Pre-bronchodilator) ${ }^{*}$} \\
\hline Stage 3 or 4 & 2.68 & $(1.51,4.75)$ \\
\hline Stage 2 & 1.60 & $(0.94,2.69)$ \\
\hline Stage 1 & 1.12 & $(0.63,1.98)$ \\
\hline Restricted & 2.25 & $(1.04,4.86)$ \\
\hline Normal & 1.00 & \\
\hline \multicolumn{3}{|l|}{ Stage (Post-bronchodilator)* } \\
\hline Stage 3 or 4 & 2.46 & $(1.63,3.73)$ \\
\hline Stage 2 & 1.11 & $(0.82,1.51)$ \\
\hline Stage 1 & 0.74 & $(0.52,1.06)$ \\
\hline Restricted & 1.36 & $(0.74,2.47)$ \\
\hline Normal & 1.00 & \\
\hline
\end{tabular}

*Modified chronic obstructive pulmonary disease stage, as defined in methods

\section{Acknowledgements}

The authors thank the staff and participants in the Lung Health Study for their important contributions. The LHS was conducted and supported by the National Heart Lung and Blood Institute (NHLBI). This Manuscript was not prepared in collaboration with investigators of the LHS and does not necessarily reflect the opinions or views of the LHS or the NHLBI. The authors would also like to thank Ms. Susan Mittenzwei and Ms. Rebecca Copeland for their assistance in this project. The analysis and development of this manuscript was supported by a research grant from GlaxoSmithKline Pharmaceuticals

\section{Author details}

1University of Kentucky, College of Public Health, Lexington, KY, USA. ${ }^{2}$ University of Kentucky College of Medicine, Lexington, KY, USA. ${ }^{3}$ Oregon Health Sciences University, Portland, OR, USA. 


\section{Authors' contributions}

DMM and EDG participated in the design of the study, drafting the manuscript, and interpreting the results. ASB assisted in acquiring the data, drafting the manuscript, and interpreting the results. All authors have read and approved the final manuscript.

\section{Competing interests}

DMM has served on advisory boards for Boehringer Ingelheim, Pfizer, GlaxoSmithKline, Sepracor, Astra-Zeneca, Novartis and Ortho Biotech and has received research grants from Astra-Zeneca, GlaxoSmithKline, Novartis and Pfizer. This work was sponsored by a research grant from GlaxoSmithKline. EDG and ASB declare no conflicts of interest.

Received: 14 July 2011 Accepted: 12 October 2011

Published: 12 October 2011

\section{References}

1. Mannino DM, Buist AS: Global burden of COPD: risk factors, prevalence, and future trends. Lancet 2007, 370:765-773.

2. Mannino DM, Homa DM, Akinbami LJ, Ford ES, Redd SC: Chronic obstructive pulmonary disease surveillance-United States, 1971-2000. MMWR Surveill Summ 2002, 51:1-16.

3. Minino AM, Xu J, Kochanek KD: Death in the United States, 2008. National Vital Statistics Reports 2010, 59:1-72.

4. Rabe KF, Hurd S, Anzueto A, Barnes PJ, Buist SA, Calverley P, Fukuchi Y, Jenkins C, Rodriguez-Roisin R, van WC, et al: Global strategy for the diagnosis, management, and prevention of chronic obstructive pulmonary disease: GOLD executive summary. Am J Respir Crit Care Med 2007, 176:532-555.

5. Celli BR, MacNee W: Standards for the diagnosis and treatment of patients with COPD: a summary of the ATS/ERS position paper. Eur Respir J 2004, 23:932-946.

6. Wenzel SE: Asthma: defining of the persistent adult phenotypes. Lancet 2006, 368:804-813

7. Pellegrino R, Viegi G, Brusasco V, Crapo RO, Burgos F, Casaburi R, Coates A, van der Grinten CP, Gustafsson P, Hankinson J, et al: Interpretative strategies for lung function tests. Eur Respir J 2005, 26:948-968.

8. Johannessen A, Lehmann S, Omenaas ER, Eide GE, Bakke PS, Gulsvik A: Post-bronchodilator spirometry reference values in adults and implications for disease management. Am J Respir Crit Care Med 2006, 173:1316-1325

9. Johannessen A, Omenaas ER, Bakke PS, Gulsvik A: Implications of reversibility testing on prevalence and risk factors for chronic obstructive pulmonary disease: a community study. Thorax 2005, 60:842-847.

10. Global Strategy for the Diagnosis, Management, and Prevention of Chronic Obstructive Pulmonary Disease (2008 Update). [http://www. goldcopd.org].

11. Mannino DM, Buist AS, Petty TL, Enright PL, Redd SC: Lung function and mortality in the United States: data from the First National Health and Nutrition Examination Survey follow up study. Thorax 2003, 58:388-393.

12. Mannino DM, Doherty DE, Buist AS: Global Initiative on Obstructive Lung Disease (GOLD) classification of lung disease and mortality: findings from the Atherosclerosis Risk in Communities (ARIC) study. Respir Med 2006, 100:115-122

13. Engstrom G, Hedblad B, Nilsson P, Wollmer P, Berglund G, Janzon L: Lung function, insulin resistance and incidence of cardiovascular disease: a longitudinal cohort study. J Intern Med 2003, 253:574-581.

14. Mannino DM, Buist AS, Vollmer WM: Chronic obstructive pulmonary disease in the older adult: what defines abnormal lung function? Thorax 2007, 62:237-241.

15. Anthonisen NR, Connett JE, Kiley JP, Altose MD, Bailey WC, Buist AS, Conway WA, Enright PL, Kanner RE, O'Hara P, et al: Effects of smoking intervention and the use of an inhaled anticholinergic bronchodilator on the rate of decline of FEV1. The Lung Health Study. JAMA 1994, 272:1497-1505.

16. Connett JE, Kusek JW, Bailey WC, O'Hara P, Wu M: Design of the Lung Health Study: a randomized clinical trial of early intervention for chronic obstructive pulmonary disease. Control Clin Trials 1993, 14:3S-19S.
17. Anthonisen NR, Lindgren PG, Tashkin DP, Kanner RE, Scanlon PD, Connett JE: Bronchodilator response in the lung health study over 11 yrs. Eur Respir J 2005, 26:45-51.

18. Anthonisen NR, Skeans MA, Wise RA, Manfreda J, Kanner RE, Connett JE: The effects of a smoking cessation intervention on 14.5-year mortality: a randomized clinical trial. Ann Intern Med 2005, 142:233-239.

19. Hankinson JL, Odencrantz JR, Fedan KB: Spirometric reference values from a sample of the general U.S. population. Am J Respir Crit Care Med 1999, 159:179-187.

20. Scanlon PD, Connett JE, Waller LA, Altose MD, Bailey WC, Buist AS: Smoking cessation and lung function in mild-to-moderate chronic obstructive pulmonary disease. The Lung Health Study27. Am J Respir Crit Care Med 2000, 161:381-390

21. Celli BR, MacNee W, Agusti A, Anzueto A, Berg B, Buist AS, Calverley PMA, Chavannes N, Dillard T, Fahy B, et al: Standards for the diagnosis and treatment of patients with COPD: a summary of the ATS/ERS position paper. European Respiratory Journal 2004, 23:932-946.

22. Sterk PJ: Let's not forget: the GOLD criteria for COPD are based on postbronchodilator FEV1. Eur Respir J 2004, 23:497-498.

23. Calverley PM, Burge PS, Spencer S, Anderson JA, Jones PW: Bronchodilator reversibility testing in chronic obstructive pulmonary disease. Thorax 2003, 58:659-664.

24. Perez-Padilla R, Hallal PC, V+ízquez-Garc+ja JC, Mui+io A, M+íquez Ma, L +'pez MaV, de Oca MaM, T+ílamo C, Valdivia G, Pertuz+ 7 J, et al: Impact of Bronchodilator Use on the Prevalence of COPD in Population-Based Samples. COPD: Journal of Chronic Obstructive Pulmonary Disease 2007, 4:113-120

25. Hansen EF, Phanareth K, Laursen LC, Kok-Jensen A, Dirksen A: Reversible and irreversible airflow obstruction as predictor of overall mortality in asthma and chronic obstructive pulmonary disease. Am J Respir Crit Care Med 1999, 159:1267-1271.

26. Burrows B: Predictors of loss of lung function and mortality in obstructive lung diseases. Eur Respir Rev 1991, 1:340-345.

27. Postma DS, de VK, Koeter GH, Sluiter HJ: Independent influence of reversibility of air-flow obstruction and nonspecific hyperreactivity on the long-term course of lung function in chronic air-flow obstruction. Am Rev Respir Dis 1986, 134:276-280.

28. Kanner RE: The relationship between airways responsiveness and chronic airflow limitation. Chest 1984, 86:54-57.

29. Tashkin DP, Celli B, Decramer M, Liu D, Burkhart D, Cassino C, Kesten S: Bronchodilator responsiveness in patients with COPD. Eur Respir J 2008, 31:742-750.

30. Lederer DJ, Enright PL, Kawut SM, Hoffman EA, Hunninghake G, van Beek EJ, Austin JH, Jiang R, Lovasi GS, Barr RG: Cigarette smoking is associated with subclinical parenchymal lung disease: the Multi-Ethnic Study of Atherosclerosis (MESA)-lung study. Am J Respir Crit Care Med 2009, 180:407-414.

31. Agusti A, Calverley PM, Celli B, Coxson HO, Edwards LD, Lomas DA, MacNee W, Miller BE, Rennard S, Silverman EK, et al: Characterisation of COPD heterogeneity in the ECLIPSE cohort. Respir Res 2010, 11:122.

32. Han MK, Agusti A, Calverley PM, Celli BR, Criner G, Curtis JL, Fabbri LM, Goldin JG, Jones PW, MacNee W, et al: Chronic obstructive pulmonary disease phenotypes: the future of COPD. Am J Respir Crit Care Med 2010 182:598-604.

doi:10.1186/1465-9921-12-136

Cite this article as: Mannino et al:: Pre- and post-bronchodilator lung function as predictors of mortality in the Lung Health Study. Respiratory Research 2011 12:136. 